\title{
研究ノート
}

\section{学術管見 続訪中彙報}

一畣族探訪と湖南を中心とした楚文化の探索一

\section{白鳥芳郎}

昨1983年の秋，すなわち同年 9 月15日より10月 8 日まで24日間に亘り私は, 日本学 術振興会の外国派遣研究員として訪中し，かつまた中国側からは中国社会科学院民族 研究所の招待を受けて特に華東南沿海諸省並び華中すなわち湖南省長沙市等をたずね, その地に住む少数民族村落を見学し, あるいは杭州, 福州, 広州, 長沙等各地の大学 をはじめ博物館その他民族学院等々研究機関をたずね, 各地で温かい歓迎を受け，各 所で講演会・座談会が開かれて, 数多くの学者研究者と対談し, 親交を深め, 予想以 上の大きな知識を吸収する僥倖に恵まれたのである。

私はこのよらな素晴しい研究旅行を了えて㷌国し，まだ興奮のさめやらぬ中に，そ の旅行中に各地で体験した貴重な見聞や対談を記録にとどめておくことは，この方面 の研究に関心を抱く同学諸士にも寄与する所少なからざるすのがあると信じ, ここに 私の旅程にそって中国学者と対話した諸問題について記録をとどめておく必要を痛感 した次第です。従って, この旅行中に話題になった種々の問題について, 個々に亘り 詳しい説明や検討を加えてゆく樶もないので，甚だ不本意ではあるが，私が特に興味 を覚学かつ今後の南部中国の研究に役立ち得ると判断した諸問題について，私のきき 書きノートにそって，そこで話題となった諸問題について緅っておくことにした。

従って本稿は決してまとまった緻密な研究報告ではなく，たた問題提起を意図した 簡単な私の研究ノートにすぎないるのであることをあらかじめお断りしておきたい。 なお本稿の題目に「続訪中举報」と「続」字を記入したのは, 既に㷌国直後, 北京帯 在中に行なった中国社会科学院民族研究所あるいは中央民族学院民族研究所で私が講 演したり，座談会の席上で討議された問題をとり上げ既に「上智史学」28号に「学術 交流・訪中策報一粨族と畣族の関係と中国民族学研究の現状」と題して, その一端を 報告しているので，本稿では北京を皮切りとしてスタートして巡り歩いた各地に拉け る学術的対談並びに体験を上記報告の続編として執筆したからである。るとょり今回 
東南アジア一歴史と文化一 No. 13, 1984

敢えて訪中し, 主として華東南沿海諸省並びに華南湖南省周域をたずねとの地に視察 調查を行ないたいと意欲を燃やした第一の理由は，この方面に広く分布を見せている 畜族と瑫族の分布とその接触移動経路あるいは両者間に見られる民族的親縁関係をた ずねたいと考えたからに外ならない。筆者はさきに西北タイ山地民族調査の折，はか らずも入手出来た瑤族の通行証ともいうべき「評皇券牒」なる記録文書から，(ここ に入手した「評皇券牒」なる巻物の全文は，既に筆者の編集した『東南アジア山地民 族誌』〔1978年，講談社〕及び同じく筆者の編になる『砟人文書』〔1975年，同上〕参 照。）あるいは瑤族の間に長く伝承されている種祖伝説から彼等が，浙江あるいは広 東の北より南方に移動した経路が分り，かつそれがさらにヴェトナム，ラオスを程由 してタイ国にまで移動して来たといら径路を知ることが出来た。このような文書や諸 多の論文または文献から，歴史を通して華南に広範囲に亘って分布する瑤族の移動経 路をたずねている中に, 瑤族の源郷は湖南省武陵の地に求められ, その地を出発点と して東南は福建省や浙江省の山岳地帯に，南方には広東省や広西方面に，あるいは西 南方面には貴州, 四州, 雲南, ヴェトナム, ラオス, タイへとその移動の足跡をのこ していることが明かになって来た。

このよらに瑤族の移動経路を探っている中に, そこに極めて興味ある問題が浮び上 って来た。それは従来, 所謂苗=濖語族と称されているような瑤族と苗族との接触交 流及びその両者間に見られる親縁関係が甚だ複雑多岐なるのであり，それにも増して もら一つの問題はこれまた畺=畮語族としばしば通称されている令族と䍙族との接触 交流についても両者の同祖神話などに見られる種族的親縁関係が求められ，このよう な苗・瑤・畣三族が一体どのようにして形成されてきたかと云ら華南民族文化史を考 える上で極めて重要な問題が，より詳細にたしかめられねばならなくなって来たから である。

長年に亘りこのよらな問題に関心を抱いていた筆者は，たまたま1981年11月より 12 月中旬まで約三週間に亘り北京や貴州として広西，雲南へと華南に扣ける少数民族の 各村寨を見学するための訪中旅行を実施した。その折，筆者は，はからずす北京にお ける中央民族学院民族研究所において，その資料室に保管されている會族祖図「祖像 流芳」なる極めて珍らしくかつ貴重な絵巻軸を閲覧する機会を得，同所の林燿華教授 の御好意によりその絵巻の全図を複写撮影することを許された。この會族祖図「祖像 流芳」は既にその全文を訳して〔松本信広先生追悼論文集（稲・舟・祭）1982年 9 月了に紹介したが，この畋族祖図に記述されている䡒族の種祖説話の筋書は一部種祖 たる竜犬槃款の生誕が大耳婆の左耳より生まるといら点を除けば，殆んどその説話の 
学術管見 続訪中菓報

内容は響に私が西北タイの山地瑤村において入手した「評皇券牒」の文面と類似する ものである。そこに先ず種祖説話の面から見れば畣族と璠族は種祖を同じくしている といら問題が考虑されねばならなくなって来たのである。そして倉族と璠族の起源問 題からその移動の経路あるいはその分岐の原因などを探索して見る必要を感じ，その 実態をさぐる意味で敢えて會族と瑤族の多く居住し，分布している地域を選び，主と して浙江, 福建, 広東, 湖南といら地域に視察旅行を試みたわけである。

\section{杭州啖話}

さて筆者は以上の如き目的の下に心いさんで, 1983年 9 月 20 日, 北京の宿泊所であ った燕山賓館を出て，午前中は中央民族学院民族研究所を訪ね，また中央民族学院の 図書館及び資料室をゆっくり閲覧させて頂いた。この時私の案内をして下さったのは 同学院民族研究所の付所長をしておられる黄淑娉・徐仁㮴両先生で, この御両人は共 に會族譃族研究の専門家であり, 既に実地調査に30有余年の実績をすっておられる方 方である。私は徐仁賥先生から地図を開きながら會村落の分布地域を教えていただ、 たが, 杭州から僅か 2 ・3 日の滞在中にどれほどの畜村が訪問出来るか甚だ心配であ った。こらして同日午後 4 時の便で杭州に向ら。杭州空港では同地民間文芸研究会浙 江分会 (文学連合会), 副秘書長の陳徳来先生と杭州大学歷史学部部長の沈煉之教授 の出迎を受け，ひと先ず風光明媚な西湖の畔にある杭州飯店別館西冷賓館（318号室） に落ちつき, 直ちに杭州大学歴史学部歴史学科を訪れた。当日, 生憎民族学を専門と する先生方が不在で, 専らフランス史を専攻されておられる沈鍊之先生の御世話にな ったが，沈先生の御配虑で民族学関係の専門家で文化庁付庁長の毛昭晣先生に紹介さ れ，二年前に開設されたといら文物学科はじめ杭州博物館に案内され，同大学の文物 資料館などを見学して, 種々杭州大学における民族学研究の実情について説明を受け ることが出来た。

私はまず杭州大学訪問の第一声として酉族について陳徳来先生に質問を発した。同 先生はこの地に住む多くの會族の間には畣族図譜が保持されていると云われ, 少数民 族の場合には先祖を崇むという意味でこの種の絵巻が保有されている。しかしその多 くは清代のあのであり, いまではこの図譜を保存している人る少なくなっていると云 ら。もともとこのような図譜は漢族の影響を受けて作られたもので, その知識も漢族 から得たすのであると云う。

現在, 䡒族は殆んと漢人と結婚しているが, 䡒族に関する古い情報は彼等の間に伝 えられている歌から求めることが出来る。この歌には昔から手で書き緅られて伝えら 
東南アジア一歴史と文化一 No. 13, 1984

れてきたるのが沢山あるという。

陳先生は賞つて畣族文学史を書いたことがあるがまだ出版されていないといわれ， 甚だ残念に思った。杭州には「畣族民間文学研究学会」なるすのがあるが，この研究 学会は浙江省と福建省との合同によって行なわれている。しかしこの学会の本部は浙 江省だけにあるという。「今年（1983年）11月，温州の文成県で蕃族䎶謡大会が行な われることになっている」と云われたが, その成果がどのような形で表わされるか期 待される。な怙杭州大学には既に引退され, 専ら著作活動を行なっている陳珠君先生 がおられ，民間故事・伝説神話あるいは民間童話などの蒐集や研究を行なら研究会が あり「奔月」なる出版物を発行している。陳徳来先生の話では, 少数民族の中には元 来竜の観念はない。竜に関する信仰や行事は漢族の影䇾によってはじめてすたらされ たものであるという。このような対話の中に，筆者もしばしばその真偽について自問 自答させられたのである。なお，同じく陳徳来先生の話によれば，畋族は漢族と結婚 するが，その場合漢族の人は畜族の姓に従わねばならぬといら風習がある。平陽には 會族の家譜，李姓の家譜が残っているといら。このような家譜は，會族と漢族との関 係を調べる上に大変貴重な資料といえる。

極めて淡々とした対話の中に, 浙江地方における畣族の習俗や文化, 漢族との関係 などを理解するための貴重な聞き書きが得られるわけである。なお，上記した陳珠君 先生は浙江省展覧館金紅転に所属されており，また陳徳来先生は浙江省民間文芸研究 会淅江分会の副秘書長であることは前述した通りである。

筆者は翌 9 月 21 日, 午前は陳徳来, 陳珠君両先生の案内で杭州博物館を見学, 午後 は嘗つて四庫全書が収蔵してあったといら文蘭閣を見学, 夜は西冷賓館の屋上で催さ れた中秋明月を眺める宴会に招かれ杭州の地にあざやかな満月を仰いたのである。次 の日22日は沈錬之教授のはからいで, 西湖遊覧の楽しい一時を過し白堤や蘇堤の湖面 に影を映す保俶塔を仰ぎ，この地の名産と云われる蓮根の粉洙をとかしてのむ藕粉 （亠̄ fen）といら暮湯にも似た珍味や，この地特産の名茶竜井茶に喉をらるおしその 後で古書店巡りをして一かかえほどの書物を購入し悦に入り宿に戻った。翌23日私は 杭州大学の博物館を見学したが, 考古学に詳しい毛昭晰文化庁付庁長は恰度御不在で お会いすることが出来なかった。

浙江の地は云うまであなく古えより呉・越王国の栄えた地であるので，考古学的な 見地からしても甚だ興味をそそられる地なのである。

有名な河姆渡遺趾の出土文物なども，浙江省博物館に展示されているが，まだ標本 遺物そのものは余り多くは展示されてはいなかった。 
従って我々はこの河姆渡出土文物の実態については, いまの処, 「考古」,「考古学 報」，「考古文物」等の出版物に多くたよらざるを得ない。

浙江省博物館には先史時代の遗物から現在の発掘品まで陳列されているが，宋代特 に南宋時代に関する出土文物には特色のあるすのが多い。例えば青銅器や陶磁器の展 示物は豊富であり，属目に価するすのも多く陳列されていた。ただ私が探しもとめた 銅鼓とか陶鼓に関するすのはまだこの地では発見されていないということであった。

なお,この杭州大学の図書館には南朱時代の文集, 筆記あるいは地方誌が多く集め られているという。特に淮河, 銭塘江方面の地方誌も多く, このような歴史・地理的 研究者としては同大学地理学科の陳槁駅教授が扣られる。是非お会いしたいと乞うた 所, 目下日本の大阪市立大学に留学中だといらことで, この地方の地方誌関係に関す る詳細な説明をらかがらことが出来ず残念であった。㷌国したら大阪に同教授を怙訪 ねしょらと思いながらこの図書館を去った。筆者がこの地の古書店で求めた『西湖集 覧』上，下二帙を宿に㞍って頁を開いていると，銭塘江といら河川名の旧名が浙江で あると記されており，その銭塘江に臨む大湖が西湖なのである。従って杭州の歴史, 即ち古くは呉越の歴史を知る上にとってこの西湖の歴史を見のがすことは出来ない。 西湖に関しては明代の田汝成の輯撰になる『西湖游覧志』及び『西湖游覧志余』なる 書があり, 両書とも1958，1980年に再版が上海古籍出版社から出版されている。ちな みに私は，この銭塘江や西湖の周辺に古来竜舟競漕なる行事があったか否かを陳徳来 先生にたずねて見た所，そのことは田汝成撰『西湖游覧志余』の「筆記」の中に記されて いるといら答えが返って来た。実は私共はここ数年来沖秝・香港を中心として古くよ り洞庭湖周辺で行なわれて来たと云ら竜舟競渡（漕）に関する歴史民族学的実地調查 に打らこんでいるので, もしかしたらこの杭州の地にもこれにちなんだ競漕の行事が 行なわれているのではないかといら関心から発した質問であったのである。事実さき に訪ねた大学図書館内で閲覧した一書に宋, 四水潜天輯の『武林旧事』〔西湖書社版 1980] なる書を開いて見たらとこに競漕について触れている文章があったのである。 浙江周域の民俗文物についてはその地に住む倉族をはじめとして，その歴史や文化史 に関する知識は案外我々の知識の中に疏んぜられていることが多い。そのような意味 からも『西湖游覧志』、西冷遊記』，または『吳越略志』など見るべき書物す多く， これらの書はみな『武林掌故䟴編』の中に収められているものである。その他, 地方 誌について翟宣頴の『方志考』民国19年（1930年） 3 巻本,『方志考稿甲集』天春書 社，など見るべき文献が多く存在することをこの地で学ぶことが出来たのである。 さて筆者が今回浙江省杭州を訪ねたのは，この地に會族村を見学するのが第一目的 
東南アジア一歴史と文化一 No. 13, 1984

であったのではあるが，いざ杭州に来て見ると，會族村を訪ねるには少なくとす 2 ・ 3 日の滞在を必要とし, 前もってその連絡準備をととのえておかなければ, 急に鈿族 村を訪問することが難しいことが分っだ。既に『中国少数民族簡史丵書』中に収めら れている會族簡史 〔《畣族簡史》編写組, 福建人民出版社版1980年]の巻頭にかかげ られている會族分布略図を見ても杭州市に一番近い畣族村は臨安とか昌化あるいは桐 盧などといら地点にあって，それらの地を訪れるには $2 \cdot 3$ 日の滞在を予定せねばな らず，かつ道路事情やバスを用意したり案内人を見つけたりすることすあり，ことは そう簡単ではなかったのである。

事実，會族分布略図を見ても分るように，浙江省で會族が多く住んでいる地方は, 主として南部地方, 特に温州市以南の山地から福建省の福州につらなる地帯であって, 畣族村を見学するのは寧ろ福州市に入ってからの方がより便利であることが分ったの である。そこで一応初期の計画を断念して，私は旅程計画通りの日程内に福州に赴く ことにしたのである。

これまで會族に関する論文などはいくつもあるが，現在我々が會族研究について一 番手近に見られる好著は上記した『會族簡史』であり, その内容も極めて充実したる のであり, 古今の学者の調查報告の類が多く引用され検討されていて甚だ参考に供し 得るものと思われる。

ちなみに, 上記『會族簡史』第一章, 令族の名称と来源の章を見ると，13世紀の中 葉, 即ち南宋の末年に史書の上にはじめて “會民”と“举民” の名称があらわれたと 云われ, 劉克庄 $(1187 \sim 1269)$ の著した《漳州諭罍》の一文に「會民不悦（役）, 畣 田不税, 其来久矣」とあり, 畣民には㽞役も租税も課せられていなかったことが分る。 これは正に會族と甚だ関係の深い眇族も古く隋代には「莫街」と称され, 征役が免ぜ られていた所から出た名称であるとすれば，賦役や啮役が免ぜられていた山地民族で あることは會族も眇族も共通していたことが分る。なお上記『會族簡史』に次いで, 1982年に『中国少数民族簡史叢書』として広西民族出版社より出版された瑤族簡史と 畣族簡史を比較しながら熟読して見ると，響族と眇族の分布をはじめ，両者の地理的 接点や移動の経路に拈いて両者の間に極めて類似点の多いことが読みとれ，今後, 種 祖神話を同じくする両者の民族的, 文化史的関係がいよいよ䦐明されてくるすのと思 われる。

杭州を去る前に杭州大学の文物資料室で見学した展示物について $1 ， 2$ 印象に残っ たものに触れて执きたい。そこでは資料室主任の楼子芳, 文物博物館教育研究室の戴 爾䌞, それに南北朝史及び宋史に造詣の深い咅延明の諸先生の案内を受けた。この文 
物資料室はそれほど大きな室ではなく，こじんまりとした展示室であったが，展示物 の中には数多く注目に価するすのが陳列されていた。主として浙江省地方で発掘され た遗物であり，その中には漢代のもので杭州漢墓出土の船上生活者の模様をそのまま 残している船が展示されていた。この船は勿論実物大のものではなく，小型のもので あるが，漢代における水上生活者の生活様相を物語ってくれる興味深い遺品であった と思われる。との他, 同じく漢代のものと思われる碓, すなわち踏臼とか秦の量器, あるいは王䒭時代の苏量, あるいは秦権すなわち秦代の計量器に用いる分銅すあり, これらの計量器具も, 上智大学に設けられている計量史研究室の蒐集に協力している 私にとって，すべて興味がそそられるものであった。この資料室では写真撮影が許さ れなかったので, 一つ一つノートにその形式をスケッチして持ち㷌っては来たが，い まこの稿にスケッチを挿入することが出来ないので, 残念ながら他の機会にゆずるこ ととする。

\section{福州談話}

1983年 9 月 24 日，民航便で杭州より福州まで飛ぶ予定であったが，急にこの便が欠 航となり，私は通訳王偉氏とともにその日の午前中は杭州の名所九里松の道をドライ ブして霊陰寺を見学, その寺院内に安置されている観音像に詣でて, その境内を散策 した。こらして同日夜行列車で福州に向い, 翌25日冝頃車空の景色に見とれながら福 州駅に到着した。駅頭には福建省民族事務委員会の雷佰春先生（畣族出身）と福建師 範大学歴史系の陳元煦先生の御二人が出迎えに見えていた。我々は福州市の華僑飯店 （618号室）に招かれ，一息ついた後，午後は上記両先生から䡒族のことについて色 色と教えて頂くことになった。この御両人の括話の中には，先にす述べた『畣族簡 史』に記載された内容と多く重複するすのああるが, その中には簡史には記述されて いない談話すあるので，その聞き書きしたすのをここに紹介しておきたい。

先ず倉族の名称の来源やその意味，またその種族に見られる主な姓とそれにまつわ る伝説など，雷先生は自ら會族であるので色々話をして下さった。これはとても興味 深くかつ参考になる談話であった。

一般に會族の分布は広いがそこにはどれほどの方言があるかをたずねて見ると，雷 先生の答えは「會語は一種だけである。しかし地方方言の言葉を借りているるのる多 いが，會族相互の間では，どこに行っても通じる」といらものだった。

また會族は刀耕火種の民と古くから云われているが本当の自称はなんと云っている かとたずねて見た。雷先生の答えによれば畣は shê (シェ) と云われているが，それ 
東南アジア一歷史と文化一 No. 13, 1984

は漢人たちが称する名称で, 自分たちは shê とは云わない。自分たちは山哈と自称 している。もともとは三哈といった。なぜなら姓が三つあって三哈というようになっ たが山頂に住んでいたので山哈といった。哈とは「人間」の意で, 哈は「客」の意と 一般には云われているがそれは事実ではない。

それなら三哈と云われるよらになった三姓とはどのような姓があるのであろらか。 即ちその姓は藍・雷・鐘の三姓である。実際にはすっとあると考えられその中には 点・盤両姓すあった。

更に雷先生の話では，畣族にはもともと四姓あった。盤姓は戦いの時に絶えてしま っだ

即ち藍氏族譜には盤姓がなくなったことが記されている。五代の頃, 閩王, 王審知 に率いられて福建の連江県馬番道にたどりついたことが藍氏族譜に記されており，こ こで盤氏一党が大風にあい，その途次盤氏はすべて減んでしまったという記録が残さ れているという。なお他地方の會にあ盤姓はない,といわれる。

残念ながら筆者はこの藍氏族譜を調べる啹がなく雷氏の語るままに聞き書き文を載 せるに過ぎない。また他地方に盤姓がないという点にもその真為をたしかめる樶がな いが，瑤族との関係に拈いて會族にも盤姓があったと思われる。その関係がまだよく 調査されないが今後の研究課題の一つになると思う。

なお馬其道とは福建の東南部福州から100km以内にある所で広東からも遠い所であ るといら。しかし，會族も瑤族も共に盤皇説話をもっている。五嶺の地以東は瑤で， 以西は倉といわれる。民族は時代とともにしばしばその住地, 名称は変わるが雷先生

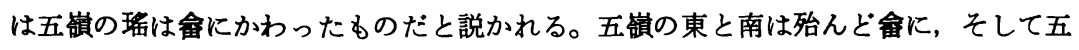

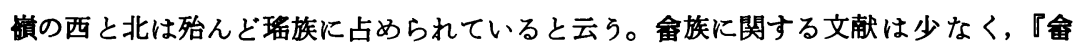
族祖図』にかぎられていると云われる。槃㼋の誕生については, 高辛から出たと云わ れているが，これは単なる伝承説話でその真偽の程は明らかにされるすのではない。 食については三つの観点がある。

最近は, 會は越の末裔であると云われている。もら一つは畣と瑤が同一起源である と云われている。そして箵というのは東夷, 徐夷といわれていた。なぜなら畣といら 字は最初は徐といら字ではなかったかという論もある。只, 東夷と徐夷は同音である。 このような意見は既に故人となった中央民族学院の教授番光旦といら先生に依って説 かれていたものである。

會族の主なる姓に関する族譜・家譜は幾種位あるかといら私の問に対し, 雷先生は 四姓に関する族譜がある，と云われた。瑤は十二姓からら始まっているけれどす畣は 
僅か四姓にとどめられているといらことも両民族の関係を探る上に一つの課題となる であろう。

雷先生が云うには, 福建の苓は広東から移って来たのはごく一部であるという。會 は福建 (閩西) の土着人であったと云える。

なお， 陳元煦先生の説明に依れば，明清時代多くの資料に依ると，閩東と浙江省の 南の畣は大体, 明末清初の頃, 広東から移って来たすのであるといら。また陳先生が 云うには, 倉の移動説に就いては学会では二説ある。一つは白鳥説の如きもので, こ の考え方を初めて云い出したのは明代の謝淛撰になる『五雑沮』（上・下）に記録さ れているあのである。この『五雑沮』は単行本であって叢書には入っていない。それ は福建省の図書館に納められており，また北京中央民族学院の図書館にもある。

更に陳先生は倉の起源問題は不明であり, またその歴史年代す不詳である。従って 會族社会の発展の歴史も詳細に知ることは難しい。この會族問題は学会でも討議され てきたがまだ結論が出ていないといわれた。

更に陳先生は慗都伝説に就いて以下の如く説明された。畣族瑫族苗族はみなこの柴 教质説を持っている。その来源は殆んど後漢書の南蛮层に出ずるすのが多い。捜神記 （晋）に出ずるとするものは少い。『玄中記』にも出てくるし『南史』にも出てくる。 そして現在も全族には犬の頭がシンボルとして残っているが，彼等の間ではそれを犬 とは云わないで竜斿と呼ぶ。畜族は愁都を信じているが, 高辛の話は神話であると信 じられている。そこに高辛とは漢族か倉の祖かといら疑問が生じてくる。

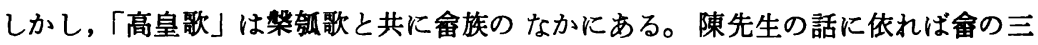
公主に閔する物語があるが，この三人の女姓がまた信仰の対象となっているので, 或 いはその地方に於ける媽祖信仰とも棼がりがあるとす思われる。

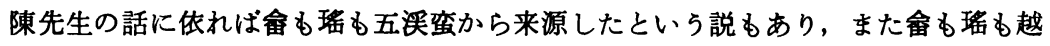
から出たとする説すある。このよらな考え方は杭州大学の徐規先生の唱えているもの である。しかし残念乍ら今回私はその徐先生と会ら機会を得ることができなかった。

そして陳先生は又, 隋書の南蛮伝にも記されているが蛮獠と倉が関係ありと考えて おられる。そして清代の雲爰庁志に依れば雲霞の地には王通廟があってその廟の前に 柱があり, そこには藍雷盤といら三文字が刻まれているとのことである。若しこの地 に上記三文字があるとすれば，これは會族の間に見られる主な姓とす無関係ではない と私には思われた。

昔から福州で有名なのは蒲田とか眉州を発祥地とするといわれる媽祖信仰であるが， その信仰が普及しているか否かを尋ねてみた。すると陳先生達は媽祖廟は昔はあった 
東南アシシア一歷史と文化一 No. 13, 1984

が現在は無い，但し蒲田と眉州には存在しているし，主として台湾には多くある，と 云われた。

なお，陳先生は酉族の源は越とする説が多くあり，また越王勾践の子孫であるとい ら説もあると語り，そのことは龐新民の「越王勾践の子孫移民考」に記されている。 また徐松石先生もかつて會族の来源を「山越来源説」の論文の中で説いておるといわ れ，また厦門大学の教授伝衣凌先生の「福建鈿姓考」の説ああるといわれた。

このような諸説に基づき, 陳先生すまた畣族は越の子孫であると考劣られると云っ て扣られた。その他陳先生は，會族の族譜家譜について以下の如く述べられた。

會族自身の持っている家譜を見せて貪らと，そこに藍雷鐘の三つの家譜のあること が確かめられた。そしてこの愈族の歴史に就いては畣族の先祖と考えられる蛮僚の前 は山越であった。従って畜族の系譜はこの蛮僚とか山越両者との関係を考える必要が ある。

なお，その蛮僚と称されるものの中に以下の如さ民族名が現われてくる。即ち(1)蜒， (2)俚，(3)僚，(4)㐌，これらはすべて少数民族の名称として現われて来るあのであるが， これに匹敵する民族名を宋代に求めれば，即ち(1)蜒は蛋に当り，(2)俚は黎，(3)僚は瑤， (4)他は不明であると考えておられる。

同じく陳先生が云われるには劉克庄の「漳州諭會」（後村先生大全集巻93）に「在 漳州叫䡒」とあり，即ち漳州に居る少数民族を畣と呼んでいたことを稆介している。

上記した如く福州では雷, 陳両先生のひとかたならぬ御世話になり, 現地において 畜族の情況を詳細に亘って伺らことができた。また我々は福建の民族学院福州分会に 於いて座談会を行い，華南文化史並びに少数民族の系譜的研究について私の研究上の 抱負を述べ，また非常に座談会も友好裡に行われ，予想以上の学術交流の目的を果す ことができた。私は浙江の杭州において酉族の村塞を訪ねる機会を逸してしまったの で，今この地においてその機会をのがせば長年の念願であった畣族村の見学ができな くなるのでなんとしてもこの際會族村の見学を実現させてほしいと強く依頼した。幸 い, 今までの私たちの対話から私たちの熱意が汲まれ，普通なら突然来てとても訪ね

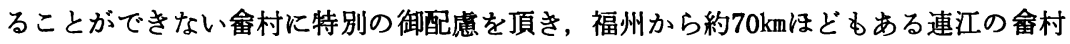
の訪問が許されたわけである。畜族出身の雷佰春, 及び陳元煦両先生の御好意によっ て, 潘渡公所副書記の黄武太先生の御助力を得て, マイクロバスを一台用意して頂き, 渓利畣村渓利大隊の見学をすることになった。さすがにこの村まではいるには渓流あ り，川を渡り，まさに私がタイ国で体験した山地民族を訪ねた時の情況と同じ光景が 目の前に開かれた。その渓利大隊に近づくに従って畜族固有の民族衣装を身につけた 
学術管見 続訪中箤

男女の姿に目がひかれ，また今までかつて見たこともない畣族の娘さんや婦人たちの 結ら髪かたちが非常に印象的に胸に刻みこまれた。

この畣村は96戸ある大きな村であって我々はその村の長老である雷其盛（71歳）, その夫人の雷奶妹（66歳）の拕宅に招待された。るちろん夫婦をはじめ村中の人々が 集まって我々の訪問を歓迎してくれた。その村はやはり小高い岡の上に位置して石畳 を踏みしめながら一段一段と歩を進め，崖ぶちは全て板状の石で積みあげられていた。 そしてそのような石を土台として，そのうえに大きな木造の家屋が建てられていて， その家の椚干から展望できる周辺の自然的景観を眺めおろし，眼下に厷々とひろがる 水田を眺めた。この溪利村にいる96戸はすべて雷を姓としていた。るちろんこの家に も系譜や家譜は昔あったと云われ，解放後は失われてしまったといら。

ただたいへん興味をひいたことは，近隣の畣村との婚姻はよく交わされているが， 遠くの畣村との婚姻は殆んどないと云われていた。この村では解放前にはやはりフニ ミスティックな祭司者もおり，それは璠族にみられる精霊崇拝の祭司者「設鬼」に相 当するすので, その祭司者は畄族の中では「法師」と呼ばれていた。家屋は入口を入 るとテーブルがあり, 客間になっており, その左隣りには大きな筈がしつらえてあり そこが料理場となっていて幾かかえもある大きな水がめもあり，また米や麦，その他 雑穀類を納めている部屋もある。炊事場から狭い階段を登って二階に行くと，老人夫 婦, 若夫婦, 子供たちの寝室となっていて，我々はその中を隅々まで見学させてもら った。今ここに写真を揭載するいとまがないので甚だ残念であるが，また別の機会に 䊅介したいと考元ている。

その他會族の天秤棒なども記念にいただき，今まで他の少数民族にみられなかった 生活用具などを写真におさめ, 短時間ではあったが一日行程でこの會村を訪ねること ができた。聞くところによると、この畣村を訪れた日本人は私が初めて，大いに感銘 して再び宿に戻った。るら一言加えたいことはこの畣族の間には竜舟祭行事が行われ ていることを知り，我々が沖繩・香港で調查を継続している行事だけに，この情報は たいへん興味深く，一度番族の竜舟競渡を見学してみたいと思いながら㷌路についた。

このようにして僅か 3 日間の滞在ではあったが, 福州に拈ける見学をはじめ学術交 流は極めて豊かなるのとなった。

\section{広州談話}

こらして筆者は, 計画日程にそって 9 月27日, 午前10時 5 分発の便で広州に向い, 広州空港には同11時10分に到着した。空港には広東省社会科学院外事科の李立先生の 
東南アジア一歴史と文化一 No. 13, 1984

出迎えを受け, 非常に近代的な大きな広州飯店に案内され，李立先生に今回の訪問は 学術交流を目的とするすのであることを述べ種々の希望を提示した。李立先生は私の 意向を充分に理解され，極めて有効な計画を組んで下さり，筆者一行を迎えて下さっ た。筆者は先ず社会科学院民族研究所並びに中山大学を訪問し，諸多の教授並びに研 究者方に挨拶をしたい旨を昖伀えした所，先ず 9 月28日早朝より社会科学院民族研究 所に怙いて盛大な座談会を開いて下さった。そこに出席された諸教授の顔ぶれは以下 の如き方々であった。即ち，

助理研究員の頼才清先生, 同助理研究員の本篗文先生 (瑤族出身婦人研究員), 広 東省社会科学院憷史研究所の李黙先生, 広東民族学院中文系の趙家旺先生（溇族出 身), 中文系民族学院の陳延何先生（畣族研究者）, 広東民族研究所助理研究員であり また民族学会の秘書長をつとめられる朱洪先生等々の顔ぶれがあつまり，中国の少数 民族，特に令族・瑤族・苗族・黎族等々に亘りそれぞれの意見が発表され，甚だ活気 に富み熱心な討議が交わされた。筆者す華南少数民族の種族系譜と華南文化史の構成 について持論を述べ，多くの先生方から貴重な意見を頂くことが出来た。この座談会 は4 時間近くも続き終りを知らぬ旺盛な雾囲気につつまれた。やはり地元の学者から 受ける示俊に富んだ意見や発言には，書物からだけではなかなか得られぬ知識が多く 教わる所大きなるのがあり，私にとって素晴らしき収嚄の多い座談会であった。

またこれに次いで, 翌 9 月29日には広東中山大学歴史学部において筆者一行をかこ さ有意義な座談会が開かれた。出席された諸先生の顔ぶれは下記の如くであった。

$\left.\begin{array}{l}\text { 童佩華 } \\ \text { 陳啓新 } \\ \text { 楊鶴書 }\end{array}\right\}$ 民族学系教授

$\left.\begin{array}{l}\text { 李松生 } \\ \text { 容観琼 }\end{array}\right\}$ 人類学系副主任教授

梁釗稪 同人類学系主任教授

胡守為 歴史系主任教授（同教授は1983年東京・京都で催された国際東洋学会議に も出席されていた）

の如き面々が一堂に会し，相互に中国少数民族の歴史や文化または系統分類あるいは 考古学等に亘り, 話題は極めて豊富であり,この座談会も三時間を超える実に充実し た学術交流の場となったのである。したがって，この座談会中に話題にのぼった主な る問題について些かその概要を述べて直きたい。

先ず人類学系主任教授の梁釗箩先生の話によれば，先ず広東省の中で人口の上で一 92 
学術管見 続訪中䉅

番多いのは黎族で，それに次いで瑤族が多い。従ってこの地では黎族と畨族の研究が 主なるのとなっている。黎族と瑤族をはじめ，少数民族の歴史研究では，慣習及び経 済が主題であり，梁教授も黎族の研究を行なっているが初期においては日本の金関丈 夫先生の研究で勉強したとのことである。な拉中国には「百越民族史研究会」があっ て，そこでは「古代越」の研究が主となっているといらことである。

他にも瑤・苗・令族の研究は行なわれているが, 広東の苗は殆んど海南島に住んで いる。なお広東の瑤はタイ国の琽と極めて類似点が多く, かつ海南島の苗族と言語は 同じである。

広東の瑤を大別すると二つに区分が出来る。一つは排瑤であり，他の一つは過山瑤 である。排瑤は語系から見れば過山瑤と同じすのであるが，方言が強く入っているの で両者は相互に通じない。それは標準語と広東語との違いと見てよい。排罾の方言の 中に広東語が多く入っている。しかし両者は共に然数信仰を同じく有している。皇清 職貢図のスヶッチや文面から見ても古い県である乳源自治県に拈ける惓の織物, 例え ばターバンの色にす 2 種あり, 1 種は白い生地の布地で, 他の 1 種は藍色の布地であ る。広東には細かに云えば 4 種類の瑤が住んでおり，連山璠や乳源の瑤をはじめ各瑤 村での髪形はそれぞれの村によって趣を異にしている。それ故髮を結ら形で，それが どこの村の璠人であるかを識別出来るといら。また乳源県には東辺覤と西辺瑤の 2 種 があり，言語の上から見ると共に過山琫方言に属しており排琫方言とは異なるすので ある。連南の璠にも二種あり，それは排譃と過山琫であるが，排璠と過山璠相互間の 会話はとても難かしくて通じないという。

瑤族の大部分は広西に多く住み, 広東には僅か一部の濖が住んでいる。広東に居る 2 種の瑤はそれぞれ衣裳を異にし，他の地方では見られないものである。また過山琫 の服装は広西賥と同じであると云われる。なお Viet Nam や Laos にいる藍靘瑤 Lan tan Yao は言語の面から云えば海南島の苗と違い, 衣裳も異にしている。海南 島の苗は広西より移動したもので言語は瑤語を話し, 風俗, 伝承は苗のそれに等しい。

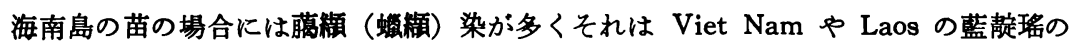
ものとよく似ているという。瑤では神事に用いる用具があり, 細長い四角の棒の一面 に馬の絵が刻まれていて,これに墨を塗って，ちょうど印符をつくるよらに紙に押す 型板棒がある。これは全く西北タイの瑤族の祭司者が用いているものと同じで，タイ の瑤族はその神事に用いる牌のことを馬牌と呼んでいたが，この広州の地では神符と 呼ばれていた。

中国学者はよく百越といら言葉を用い，どの民族は百越系だといらような「百越考」 
東南アジア一歴史と文化一 No. 13, 1984

などといらよらな著書論文が多い。しかし筆者にはここに百越と称される民族そのす のが一体どのようなるのであるか明かでないので, しばしば中国学者の論文を読んで いると戸惑いを感じさせられる場合が多い。

例えば古来史書中に現われてくる吳越の越をはじめとして南越, 東越, 閩越, 歌越, 駱越, 越裳, あるいは越南などの名であらわれてくる越字をともなら国家名や民族名 が沢山現われてくる。一体この越なるものは民族的にも風俗慣習の上からす，あるい は言語面その他もろるろの文化的要素から，これ等を一括して一つの越族集団として 把えることが出来るものであろらか。この点所謂越族の実態をもっとはっきりと分析 し解明してゆかねばならない問題があると思っている。広東, 広州と云えば漢代に南 越王国の拠っていた所であるから，この地の学者方がこの問題をどう考えておられる か質問をして見た。そうすると次のような答えが返って来た。即ち広東省では越とは 黎族と壮(僮)族の起源と関係があるといら視点から研究が行なわれているといらので ある。考古学的な面から見ても越には二つの特色があり, 一つは有段石芥, 二つには 印紋陶であるとなし, 拍打法の手法による土器製作技術はすべて越族に関係があると いらのである。銅鼓については雲南の楚雄出土のものが一番古い（劉氏説）と考えら れるが, 酒を作る䤑造器として用いられる陶器にも, 銅鼓の形態によく似ているすの があり, 海南島の黎族の用いていた陶製醇造器には全く銅鼓の原型と思われるすのが 使われていることから，両者の間に形式上の関係が考えられるとの説明を受けた。そ してこの種の陶器を用いているのは海南島の黎族であり, その黎族はまた越の子孫で あると云らのである。広東・広西両省の少数民族の言語は昔の越の言語にとても近い し，文身は昔の越人もやっていたが海南島の黎族も文身をしていたといらのである。 たしか梁釗轁教授の話であったと記憶するが，1948年以前は中国西南部を重視してい て民族学や民俗学が専門として研究していた。その頃楊成志・鍾敬文両先生はフラ ソスに留学し、『民族学研究集刊』はこの両先生によって創り出された。既に1920年 代に歴史学部, 社会学部の中で民族学や文化人類学が講義されていたが，当時はまだ M. A. の学位しかなかった。現在雲南大学の西南民族歴史研究所の主任教授をしてお られる江応樑先生もその頃のこの中山大学の卒業である。1949年以后, この中山大学 あ歴史学科で民族, 人類, 考古の講義は開講され, 社会学部ではこのよらな講義はし なかった。いまこの大学には49年以后の卒業生が沢山いる。また1980年に至り歴史学 部から人類学部が独立し, 現在人類学科には考古学部と民族学部の二つの系統があり, 教師は 30 人おり，その中には行政官も 2,3 人が含まれている。学部学生数は72名, 院生は 9 名, その中 8 名が修士課程に属し，1名は博士課程でチベットを研究してい 
る。49年以前には梁先生を含めて 2,3 人の教授は瑤, 苗を調査し, 容観琼・張寿䃆 先生すまた同行したのである。目下張寿猉教授は香港中文大学におる。1949年以后, 全国的民族調査を行ない，今日この席に参加している方たちは大部分この調査に参加 しており，主として苗族と黎族の調査に当たり，㜔佩華先生は景頗，張寿猉先生はま たよくその言葉に通じている。な挑陳啓新・楊鶴書・李松生の三先生は私梁と雲南に 行き，多くの論文を発表していて，その中には拉祜族についての社会形態の発展また は親族制度の研究が多い。また潘雄先生は黎と奍の研究に従事しているが本席には出 席されていない。

以上が中山大学の民族学, 人類学, 歴史学における教授の面々と活動の状況である と梁先生の紹介がおわった。な妳梁生は1973年から湖南省馬王堆墓の発掘に関心を 持ち，大侯夫人の衣裳やその他出土文物に現われてくる意匠紋様の中に苗族のそれと よく似ているすのがある点に注目しておられ，多分馬王堆出土文物に見られる文化的 要素の中に苗族と侗族に関係するすのがあるといら点を指摘された。そのことについ ては1979年,『民族研究』1 期に楊鶴書先生が論文を揭載しており，1980年以后も引 きつづき考古学, 民族学, 人類学に関係する学者たちが馬王堆墓について研究しはじ めたといら。例えば，1983年，『民族研究』第 4 期に雲峰氏により「馬王堆漢墓族属 問題的討論」が発表されている。この文化や墓趾が侗族に関係ありとする学者には侗 族出身者が多く，また大侯夫人のミイラを百越であると主張する説すある。るっとも 侗族も百越に入る民族であるので, 大侯夫人の族属問題については今後の研究を俟た ねばなるまい。

なお，湖南省長沙地区ではまた発掘されているのを聞かないが，銅鼓は民間的には 所有されている。青銅器問題について銅鼓をどのように位置づけられるかという点を 質問した所，中国では現在民間組織ではあるが「銅鼓研究会」といら会が広州にある という。梁先生自身の意見としては，銅鼓の雲南起源説には反対であると述べられた。 なお梁先生は浿国についても，当時代において酒国は奴隷社会であり部落社会ではな かった。石寨山出土文物中にスキタイ文化が存在することは認められると云われ，筆 者の書いた「石寨山文化に見られるスキイタ系文化」なる小論には同意を示して下さ った。

また梁先生は貴州の夜郎, 広東の南越, 江蘇の呉について, その地方に住んでいた 人々は必ずしも単一民族であるとは思えない，滇国について云えば，この国は唪族と 越族が混在して成立した国家であるといら。この滇の地はるとると越族の地であった と思われ，そこに西方から族が南下移動したのであるが，その時, 族の文化が優 
東南アジア一歴史と文化一 No. 13, 1984

れていた。従って南下して越を平らげ滇国をつくった。それ故奴隷主は熟族であった と考えられると述べられた。この点では筆者の見解と一致する面はあるが，そこに越 族が住んでいたといら明かな証拠もないし，かりにいたとしても当時どのような名称 であらわれていたかはまだ明かにされていない。唐代南詔王国形成の六詔の中に越析 詔という名称は出てくるわけであるが, 私は當つて南詔問題を論じた折，その六詔の 詔主は皆な族乃至納西系の民族であったことは明かであり，その先住族たる住民は 白蛮たる平地農耕民であったと主張した。これら白蛮が越族であったか否か, 越族の 実態がまだ明かにされていない現時点に拈いて，滇国は族に越族が支配されること によって成立したか否か断定するのはまだ時期尚早の感を禁じ得ない。すっとも滇王 の名が当羌といらのであるからこれも北方遊牧民族の姜族の一味ではなかったかとい ら推論を私もかつて書いたことがある。

梁先生はまた云う。越が自から青銅器時代に入る前に, 中原の木鼓をそのまま取り 入れていた。それは越の部落において権力の象徵でありかつ神聖なものであった。し かし奴隷社会に入るには部落の権力をなくさなければならない。だから奴隷衆は銅鼓 の上に模様・意匠をつけたものである。銅鼓の意匠模様の中にスキタイ系の形が現わ れているのは姜族の影響があったからであろら。また雲南省は東南アジアに近く雲南 と東南アジアの関係も考えられるが，雲南の文化はより中国との関係が深い。雲南の 石寨山で発見された銅鼓が原型であったか否かは分らない。歴史的に見れば各民族の 発展は同じ順序で発達して来たものではない，それ故雲南で発見された銅鼓について る，漢民族の技術を取り入れて独自に作られたものであるとも考えられる。

なぜなら雲南の青銅鼓の跂面や鼓側の銅板は非常に薄くつくられているが，殷の銅 鼓はとても部厚いすのである。これは技術の上で雲南の銅鼓の方が優れていたことを 示すあのであろら。また銅鼓は権力の象徵であった。そして，それ以前の段階ではあ るが，木鼓もまた権力の象徵であったと思われる。梁先生は雲南の俪族に入ったこと があるが，仾族には木鼓を安置する小屋があって，そこは極めて神聖な場所であった。 このような面から考察しても木鼓は銅鼓の前身であると考えることが出来ると述べら れた。また浙江や福建で銅鼓が発見されていないのは，銅鼓をつくるまでに既に方国 即ち地方国家をつくってしまったことによる。例えば戦国時代の楚国のよらな方国を つくっていた。それ故，早くから浙江や福建には中原文化の影響を受け青銅器文化も 早くから導入されていたに違いない。左伝には吳が越を攻める時, 越は銅鼓を取り出 して鳴らし，点は恐れて逃げたといら話も残されている。越は銅鼓を権力の象敨とし 越人は銅鼓の威勢に従属したものと思われる。梁先生はついで浙江，福建の地方は早 
く奴隷時代に入り中原の影䇾を強く受けた。木鼓の形は銅鼓の形とは似ていたといら ことは必ずしも云えない。しかし象脚鼓は木鼓に似ていることから考劣れば，木鼓と 銅鼓の関係も否定出来ないるのがあると説かれる。

考古学の上から見れば中国東南沿海地方の文化は朝鮮まで层わっている。従って現 在でも象脚站は朝鮮でも使われている。ここに中国東南沿海文化の影響は朝鮮半島と も文化的つながりを持つるのと考えられるといら。なお文中しばしば用いられている 奴隷社会とか部落社会といら用語は主としてェンゲルスの理論に基く用語概念でとら えられていることを知っておかねばならない。さて筆者は最後に訪れた湖南省長沙市 において見学した湖南省博物館の状況や，その他湖南における苗，賥土家諸族の歴史 的背景から古代楚国の住民や文化と，後世その地に現われてくる武陵蛮，あるいは莉 蛮, 五莉蛮との文化や風俗あるいは種族系譜的つながりについて長時間に亘り座談会 を行なった。しかしこの対談を本稿で紹介することは与えられた紙数の余白もなく， 時間的にも余裕が許されないので，甚だ残念ではあるが，今回の訪中萧報で最す山場 になる最後の章をここで打ち切らねばならなくなった。ここに発表出来ない部分は続 続訪中荣報として別に稿を更めて発表する予定である。尻切れとんぼの䭾文に終って しまったことは如何にも残念であり，この対談にかかげられた諸問題についてす自己 の意見を加えたいと望んでいたが，ここで筆を措くことにした。 